\title{
PENGANTAR PROSES KEPERAWATAN
}

\author{
Intan Faadhilah / 191101053
}

\section{Latar Belakang}

Perawatan adalah sesuatu yang esensial dan sangat penting yang diberikan oleh perawat terhadap individu, keluarga dan masyarakat yang bertujuan untuk menyelesaikan masalah dan memenuhi kebutuhan pasien. Pelayanan yang diberikan adalah upaya untuk meningkatkan derajat kesehatan semaksimal mungkin sesuai dengan kemampuan yang dimiliki dalam menjalankan kegiatan promotif, kuratif, preventif dan rehabilitatif dengan menggunakan proses keperwatan. Layanan asuhan keperawatan dilaksanakan oleh tenaga keperawatan yang bekerja sama dengan tenaga kesehatan lainnya dalasm mencapai kesehatan yang optimal ( Effendy, 1995). Perawat sebagai profesi yang memiliki hubungan lebuh dekat dengan pasien dalam pemenuhan kebuthannya, dibutuhkan suatu pendekatan dengan metode ilmiah dan sistematis sehingga mempermudah pemecahan masalah pasien. Metode tersebut adalah proses keperawatan (Haryanto, 2008). Proses keperawatan merupakan metode ilmiah yang digunakan untuk memberikan asuhan keperawatan uang professional. Dimana saja perawat bekerja, menghadapi segala maacam kasus, melayani pasien dalam segala tingkat usia perawat harus menerapkan proses keperawatan. Setiap perawat diwajibkan dapat memahami dan melaksanakan proses keperawatan dan diharapkan setiap proses keperawatan disususn dalam dokumentasi status kesehatan pasien (Rohmah \& Walid, 2009). Proses keperawatan merupakan aktivitas bagian praktik keperawatan yang dilakukan secara sistematis. Perawat menggunakan pengetahuan konprehensif untuk mengkaji masalah pasien, membuat penilaian yang bijaksana dan mendiagnosa, mengidentifikasi hasil akhir kesehatan pasien dan merencanakan, menerapkan dan mengevaluasi tindakan keperawatan yang tepat untuk mencapai tujuan merupakan pelaksanakan proses keperawatan (Dermawan, 2013). Asuhan profesional dituntut untuk dapat melaksanakan proses keperawatan dengan tepat dan benar. Pemahaman perawat terhadap proses keperawatan sangat penting, karena menjadi suatu hal yang utama dalam pelaksanaan asuhan keperawatan. Proses keperawatan akan membedakan asuhan keperawatan professional dengan asuhan keperawatan tradisional. Kemampuan perawat untuk menerapkan proses keperawatan tidak dapat ditawar-tawar lagi (Rohmah \& Walid, 2009). Dalam pelayanan asuhan keperawatan, proses keperawatan itu dari tahun ke tahun mengalami perkembangan yang sangat pesat. Sejarah perkembangan keperawatan sebagai profesi ditinjau dari perkembangan keperawatan dunia dan 
perkembangan keperawatan Indonesia (Hidayat, 2008). Seiring dengan perkembangan keperawatan, berbagai penemuan dalam dunia keperawatan juga diperkenalan salah satunya proses keperawatan.

\section{Metode}

Metode yang digunakan untuk memperoleh informasi dan data yaitu menggunakan metode literasi membaca jurnal, buku, dan karya ilmiah lainnya.

\section{Hasil}

- Melalui hasil literasi membaca dari jurnal, buku, dan karya ilmiah lainnya didapatkan hasil bahwa perkembangan keperawatan mengami perkembangan yang sangat pesat seiring dengan perkembangan golobalisasi baik internasional dan Indonesia. Pada awalnya keperawatan itu hanya seatu pekerjaan yang dianggap sebagai budak dan pembantu orang sakit dikalangan masyarakat, namun saat ini keperawatan itu sudah menjadi suatu profesi yang setara dengan profesi lainnya. Perawat bekerja professional sesuai dengan disiplin ilmu yang diperolehnya.

- Proses keperawatan yang pertama kali dijabarkan oleh para ahli terdiri dari 4 tahapan: pengkajian, perencanaan, pelaksanaan, dan evaluasi. Pada saart ini, proses keperawatan telah ditetapkan memilki 5 tahapan: pengkajian, diagnosis, perencanaan, implementasi dan evaluasi. Proses keperawatan sebagai pedoman dalam pengembangan standar praktik asuhan keperawatan yang diatur dalam UndangUndang PPNI.

- Menggunakan metode pemecahan masalah Pendekatan proses keperawatan memungkinkan perawat untuk mengidentifikasi seluruh kebutuhan yang diperlukan klien. Kebutuhan ini menggambarkan masalah yang terjadi pada klien baik aKtual maupun risiko. Identifikasi masalah keperawatan yang ada merupakan dasar bagi perawat untuk menetapkan desain pemecahan masalahnya. Sehingga tindakan yang dilakukan terhadap klien merupakan tindakan yang bertujuan untuk memecahkan masalah yang terjadi pada klien.

- Menggunakan standar untuk praktek keperawatan Standar praktek diperlukan untuk menjaga mutu asuhan yang diberikan pada klien. Perawat yang bertugas di tempat pelayanan dengan strata apapun, dan merawat klien dengan berbagai macam kasus, selalu menggunakan standar yang sama, yaitu proses keperawatan. Standar ini sangat penting untuk menjamin bahwa klien telah mendapatkan pelayanan yang memadai. 


\section{Pembahasan}

\section{- Perkembangan Proses Keperawatan}

Pada tahun 1950-an proses keperawatan pertama kali diperkenalkan yang terdiri dari tiga tahap yaitu pengkajian, perecanaan, dan evaluasi berdasarkan metode ilmiah yaitu, mengobservasi, mengumpulkan data, menganalisis temuan-temuan baru (Moorhouse, dan Burley, 1998)

Berbagai penemuan para ahli dalam dunia keperawatan pun diperkenalkan sejalan dengan perkembangan keperawatan. Pada tahun 1955, seorang ahli keperawatan bernama Hall memperkenalkan proses keperawatan. Namun masih hanya memperkenalkan istilah saja. Pada tahun1963, seorang ahli bernama Wiedenbach memperkenalkan tiga langkah dalam proses keperawatan yaitu, pengamatan, menyalurkan bantuan pertolongan, dan validasi (Deswani, 2011).

Pada Tahun 1967, tahapan proses keperawatan itu terdiri dari empat tahapan yaitu pengkajian, perencanaan, pelaksanaan, dan evaluasi yang diperkenalkan oleh Yura dan Wals. Pada tahun 1967 dilakukan publikasi edisi pertama proses keperawatan, dan 1973 edisi kedua proses keperawatan dipublikasikan dan mengalami peningkatan (Nursalam, 2009).

Pada tahun 1982, National Council of State Boards of Nursing menyempurnakan tahapan proses keperawatan itu menjadi 5 tahapan, yaitu : pengkajian, diagnoss, perencanaan, implementasi/pelaksanaan, dan evaluasi. Hingga saat ini proses keperawatan yang digunakan sebagai standar praktik asuhan keperawatan adalah proses keperawatan yang memiliki 5 tahapan.

\section{- Konsep Proses Keperawatan Pengertian}

Pengertian dan definisi proses keperawatan yang dikemukakan oleh para ahli keperawatan, diantaranya adalah:

Wolf dan Weitzel Proses keperawatan adalah serangkaian tindakan yang diberikan kepada pasien untuk menyelesaikan masalahnya. Rangkaian tidakan itu untuk menetapkan, 
merencanakan, melaksanakan pelayanan keperawatan dalam upaya mengoptimalkan kesehatan.

Yura Wlash (1983) Proses keperawatan adalah serangkaian tindakan yang dilakukan secara berurutan untuk menentukan masalah pasien, menentukan perencanaan, mengimplementasikan rencana guna memecahkan masalah dan melakukan evaluasi keberhasilan terhadap masalah klien.

Potter and Perry Proses keperawatan adalah suatu pendekatan secara ilmiah dalam memecahkan masalah. Perawat dapat memberikan asuhan melalui tahapan: pengkajian, diagnosis, perencanaan, pelaksanaan dan evaluasi.

Dari ketiga pengertian dapat disimpulkan bahwa proses keperawatan adalah: serangkaian tindakan yang secara berurutan dan sistematis melalui pendekatan ilmiah untuk mengatasi dan memecahkan masalah klien, dan memenuhi kebutuhan klien · pelayanan asuhan keperawatan dilaksanakan melalui lima tahap proses keperawatan: pengkajian, diagnose, perencanaan, implementasi dan evaluasi.

\section{Tujuan Proses Keperawatan}

a. Menggunakan metode pemecahan masalah Pendekatan proses keperawatan memungkinkan perawat untuk mengidentifikasi seluruh kebutuhan dan kesehatan pasien yang mungkin terjadi masalah. Perawat akan merencanakan tindakan untuk mengatasi, mengurangi dan memecahkan masalah yang terjadi pada klien.

b. Menggunakan standar untuk praktik keperawatan Standar praktik keperawatan sangat perlu untuk menjaga mutu dan kulaitas asuhan keperawatan. Perawat yang bertugas di tempat pelayanan baik jenjang pendidikan yang berbeda, namu standar praktik keperawatan adalah pedoman dan penjamin bahwa klien mendapatkan asuhan keperawatan

c. Memperoleh metode yang baku dan sesuai, rasional (logis), dan sistematis Proses keperawatan ditetapkan berdasarkan prinsip ilmiah/rasional. Proses keperawatan juga sistematis sesuai dengan tahapan yang saling ketergantungan/berkesinambungan dan setiap tahap itu tidak dapat dipisahkan.

d. Memperoleh metode yang dapat digunakan dalam segala situasi Dalan keadaan gawat, darurat, gawat darurat, akut, kronik, maupun efektif dapat menggunakan proses keperawatan. 
e. Mempunyai hasil asuhan keperawatan yang berkualitas tinggi Identifikasi masalah yang dilakukan perawat melalui pendekatan proses keperawatan akan menentukan hasil asuhan.

\section{Sifat Proses Keperawatan}

a. Dinamis Masalah keperawatan selalu berubah-ubah sesuai dengan kondisi dan situasi klien, sehingga pendekatan proses keperawatan dalam pemecahan masalah klien pun akan berubah.

b. Siklus Proses keperawatan diberikan secara siklus, mulai dari tahap satu sampai lima dilakukan secara sistematis. Apabila tindakan belum mencapai tujuan yang diharapkan maka kembali ke tahap satu.

c. Interdependen Tahapan proses keperawatan saling ketergantungan, tidak berdiri sendiri namun saling berkesinambungan.

d. Fleksibel Pendekatan proses keperawatan bersifat tidak kaku, dan luwes, mudah menyesuaikan dengan situasi, kondisi, mental dan emosional.

\section{Tahap-Tahap Proses Keperawatan}

a. Pengkajian Pengkajian merupakan pemikiran dasar yang bertujuan untuk mengumpulkan data, mengelompokkan data sesuai masalah dan mengklasifikasikan masalah berdasarkan kebutuhan pasien yang akan dipenuhi. Kebutuhan pasien terdiri dari biologis, psikologis, sosial dan spiritual (Effendi, 1995).

b. Diagnosa Diagnose merupakan keputusan klinis mengenai masalah yang dialami pasien, keluarga, dan masyarakat (NANDA, 1990).

c. Perencanaan Perencanaan merupakan susunan dalam setiap rencana tindakan yang akan dilakukan kepada klien, keluarga, dan masyarakat dalam mencapai tujuannya.

d. Implementasi Pengaplikasian atau pelaksanaan dari setiap rencana yang telah disusun, perawat melaksanakan sesuai dengan identifikasi masalah klien.

e. Evaluasi Evaluasi merupakan tahap akhir dari proses keperawatan, pada tahap ini dilakukan penilaian keberhasilan asuhan keperawatan yang telah dilaksanakan. 


\section{Penutup}

Keperawatan adalah sesuatu yang esensial dan sangat penting yang diberikan oleh perawat terhadap individu, keluarga dan masyarakat yang bertujuan untuk menyelesaikan masalah dan memenuhi kebutuhan pasien. Proses keperawatan adalah: serangkaian tindakan yang secara berurutan dan sistematis melalui pendekatan ilmiah untuk mengatasi dan memecahkan masalah klien, dan memenuhi kebutuhan klien . pelayanan asuhan keperawatan dilaksanakan melalui lima tahap proses keperawatan: pengkajian, diagnosa, perencanaan, implementasi dan evaluasi.

\section{REFERENSI}

-Asmadi. (2008). Konsep Dasar Keperawatan. Jakarta: EGC. Dermawan, R. (2013).

Keperawatan Jiwa: Konsep dan Kerangka Kerja Asuhan

Keperawat Jiwa. Jogjakarta: Gosyen Publishing

-Deswani. (2011). Proses Keperawatan dan Berpikir Kritis. Jakarta: Salemba Medika.

-Effendy, N. (1995). Pengantar Proses Keperawatan. Jakarta: EGC.

-Haryanto. (2008). Konsep Dasar Keperawatan dengan Pemetaan Konsep (Concept Mapping). Jakarta: Salemba Medika.

-Hidayat, A. A. (2008). Pengantar Konsep Dasar Keperawatan. Jakarta: Salemba Medika.

-Hutahaean, S. (2010). Konsep dan Dokumentasi Proses Keperawatan. Jakarta: Trans Info Media. -

-Nursalam. (2007). Proses dan Dokumentasi Keperawatan Konsep dan Praktik, Edisi 2. Jakarta: Salemba Medika

-Pakpahan, G.A. (2019). Pentingnya Mengetahui Berpikir Kritis dalam Asuhan Keperawatan. Osf.io

-Potter, P., \& Perry, A. (2005). Buku Ajar Fundamental Keperawatan: Konsep, Proses, dan Praktik. edisi 4. Jakarta: EGC. 
-Rohmah, N. (2010). Integrasi Proses Keperawatan dalam Pembelajaran Klinik Keperawatan ONE TO ONE TEACHING AND FEED BACK. The Indonesian Journal of Health Science, $1(1), 1-11$. 